\title{
COMPARISON OF DIFFERENT SELECTIVE ENRICHMENT STEPS TO ISOLATE SALMONELLA SP. FROM FECES OF FINISHING SWINE
}

\author{
Geovana Brenner Michael ${ }^{1}$; Roselis Simoneti ${ }^{1}$, Marisa da Costa $^{2}$; Marisa Cardoso ${ }^{1 *}$ \\ ${ }^{1}$ Departamento de Medicina Veterinária Preventiva, Faculdade de Veterinária; ${ }^{2}$ Departamento de Microbiologia, Instituto de \\ Ciências Básicas de Saúde, Universidade Federal do Rio Grande do Sul, Porto Alegre, RS, Brasil.
}

Submitted: November 05, 2001; Returned to authors for corrections: March 26, 2003; Approved: May 08, 2003

\begin{abstract}
A two-phase study was conducted to compare the efficacy of several enrichment selective-broth steps associated to different plating media for recovery of Salmonella sp. from finishing swine feces. In a first phase, Rappaport-Vassiliadis broth (RV) incubated at $42^{\circ} \mathrm{C}$, Tetrathionate Müller-Kauffmann broth at $37^{\circ} \mathrm{C}$ (TMK37) and $42^{\circ} \mathrm{C}$ (TMK42), and Selenite Cystine broth (SC) at $37^{\circ} \mathrm{C}$, in combination with three selective plating media Rambach agar (RA), Xylose-Lysine-Tergitol 4 agar (XLT4), and Brilliant-Green Phenol-Red Lactose Sucrose agar (VB) were compared for recovery of Salmonella from artificially contaminated swine feces. In a second phase, RV, TMK37, and TMK42, associated with XLT4 and VB, were tested with naturally contaminated swine feces. In this study RV, TMK42 and TMK37 were superior to SC for isolating Salmonella sp. from artificially contaminated feces. TMK42 and RV were more productive than TMK37 for recovery of Salmonella from naturally contaminated feces samples. Selectivity and indication capability of the plating media were remarkably affected by the selective enrichment step effectiveness. The TMK42/XLT4 association was the most sensitive and RV/XLT4 the most specific. The use of VB agar is also recommended to increase the likelihood of isolating atypical $\mathrm{H}_{2} \mathrm{~S}$-late producing/ non-producing Salmonella. In this study RV and TMK42 were the most efficient selective enrichment for recovery of Salmonella sp. from swine feces.
\end{abstract}

Key words: Salmonella sp., selective enrichment, swine

\section{INTRODUCTION}

In recent years the importance of pork as a source of human salmonellosis has gained increasing attention $(3,6,12)$. This microrganism has also been frequently isolated from healthy swine $(1,5,8,24)$. These facts stress the hazard that Salmonella sp. in swine represents for human health, and underlines the importance of detecting this pathogen when health control programs are concerned $(9,15,16,23)$. In control programs, the use of a effective method to detect Salmonella sp. makes it feasible to estimate the herd infection level, which is considered the best approach for epidemiological studies (18). When culture methods are considered, selective enrichment is an important step, that inhibits the competitive microbiota while allows the growth of Salmonella sp. $(2,7,14,18,20)$.
Only few studies concerned with isolation of Salmonella sp. from swine feces have been conducted. Moreover, many of these studies have used different methodologies, yielding controversial results $(10,17,18)$. Comparison of the sensitivity of culture methods is also difficult when a number of studies have only used artificially contaminated samples (18).

Thus, the aim of the present study was to determine an efficient culture method to recover Salmonella from swine feces, testing both naturally and artificially contaminated samples.

\section{MATERIALS AND METHODS}

\section{Artificially contaminated samples - First phase}

A pool of pen feces from Salmonella-free pigs were taken in two finishing farms. The feces pool was divided into seven

\footnotetext{
* Corresponding author. Mailing address: Departamento de Medicina Veterinária Preventiva, Faculdade de Veterinária, Universidade Federal do Rio Grande do Sul, Av. Bento Gonçalves, 9090. 90140-000, Porto Alegre, RS, Brasil. E-mail: mcardoso@vortex.ufrgs.br
} 
samples (25g each) and then contaminated with 1 or $2 \mathrm{CFU} / \mathrm{g}$ of: S. Enteriditis (ATCC 13076), or S. Typhimurium (ATCC 15290), or a pool of Salmonella serotypes isolated from swine feces (Salmonella sp., S. Bredeney and S. Derby). A sample of Salmonella-free feces were used as control. The samples were submitted to cold stress $\left(4^{\circ} \mathrm{C} / 48 \mathrm{~h}\right)$. After pre-enrichment in buffered peptone water $\left(37^{\circ} \mathrm{C} / 24 \mathrm{~h}\right)$, aliquots of $1 \mathrm{~mL}$ were subcultured in triplicate to $9 \mathrm{~mL}$ of the following selective enrichment broths: Selenite Cystine (SC, Difco), and Tetrathionate Müller-Kauffmann (TMK, Difco). In addition, aliquots of $0.1 \mathrm{~mL}$ were subcultured in triplicate to $9.9 \mathrm{~mL}$ of Rappaport-Vassiliadis selective enrichment broth (RV, Merck). $\mathrm{SC}$ were incubated at $37^{\circ} \mathrm{C}$ and $\mathrm{RV}$ at $42^{\circ} \mathrm{C}$. For TMK, 3 tubes were incubated at $37^{\circ} \mathrm{C}$ (TMK37), and other 3 tubes at $42^{\circ} \mathrm{C}$ (TMK42). After 24h of incubation, aliquots of the selective broths were streaked onto selective plating media: Rambach agar (RA, Merck), Xylose-Lysine-Tergitol 4 agar (XLT4, Difco), and Brilliant-Green Phenol-Red Lactose Sucrose agar (VB, Difco). After $24 \mathrm{~h}$ of incubation, up to three typical colonies of Salmonella from each selective plating medium were isolated following Holt et al. (8)

\section{Naturally contaminated samples - Second phase}

For the experiment with naturally contaminated fecal samples, individual rectal feces were taken from 126 animals in a Salmonella-positive farm in Rio Grande do Sul State, Brazil. The above described sampling was performed twice with a 40-day interval. Samples contaminated with $2 \mathrm{CFU} / \mathrm{g}$ of S. Typhimurium ATCC 15290, were used as positive control. All samples were processed following the same method described above. Nevertheless, in this experiment enrichment was carried out using for each sample one tube of each selective enrichment broth: RV, TMK42 and TMK37, and as selective media only XLT4 and VB. Suspect colonies were identified following Holt et al. (13).

\section{Determination of sensitivity and specificity}

Sensitivity and specificity were calculated using a contingency table, and results given as percentage (22).

\section{Statistical analysis}

Two artificial and two natural contamination assays were performed to detect Salmonella. Results were analyzed using the MacNemar test, with significance level $p<0.05$ (11).

\section{RESULTS AND DISCUSSION}

\section{Artificially contaminated samples}

Regardless the isolation method, no difference was found in the recovery of Salmonella from feces contaminated with 1 or $2 \mathrm{CFU} / \mathrm{g}$ (each) of all tested serotypes, so the results were analyzed together.
In the first assay, samples submitted to enrichment in RV, TMK42, and TMK37 showed no significant difference in the amount of plates with confirmed Salmonella sp. colonies. All these broths allowed a significantly higher Salmonella growth $(p<0.05)$ than SC. In recovering Enteriditis serotype, TMK42 was significantly superior to SC and TMK37, but not to RV $(p=0.07)$. On the whole, this serotype was recovered in less plates when these were streaked with aliquots from selective enrichment broths incubated at $37^{\circ} \mathrm{C}$ (Table 1).

Considering the contamination levels of 1 and $2 \mathrm{CFU} / \mathrm{g}$, for S. Typhimurium and for the Salmonella pool, it was not possible to observe any significant difference between RV, TMK42, and TMK37. Differences were seen only in comparison to SC, which showed the lowest performance. Further differences could have been detected if lower contamination levels have been tested.

When streaked with aliquots from the same selective enrichment broth, none of the tested selective agar media showed pronounced difference on recovery of Salmonella sp. This stresses that Salmonella sp. isolation conditions depend more on the performance achieved by the selective enrichment than on the selective medium itself, and corroborates the observations of Sherrod et al. (21).

Less false-negative results were found when the agar media tested were streaked with selective enrichments incubated at higher temperatures. The increase in recovery of Salmonella at elevated temperatures is reportedly due to increase in the inhibition of the competitive microbiota $(14,18,20,21)$.

In a previous study, Pignato et al. (19) were able to isolate $S$. Enteritidis from meat samples contaminated with up to $0.4 \mathrm{CFU} / \mathrm{g}$, using TMK incubated at $43^{\circ} \mathrm{C}$ but not from SC incubated at $37^{\circ} \mathrm{C}$. However in the present study, RV even incubated at $42^{\circ} \mathrm{C}$ had not the same performance as TMK42. This may be due to the higher sensitivity of the strains to the selective agents in $\mathrm{RV}$, as the plates inoculated with this broth did not show increased competitor growth that could have impaired visualization and isolation of typical Salmonella sp. colonies.

Differently from the first inoculation, TMK37 enabled a better isolation of serotype Enteriditis, followed by SC and RV in the second assay. For all tested associations, serotype Enteritidis showed the lowest number of characteristic colonies. On the contrary, the serotype Typhimurium was isolated in almost all selective media and the Salmonella pool was recovered in all plates inoculated with RV, TMK42, and TMK37. The recovery from SC was significantly lower for Salmonella pool (Table 1).

Similarly to the first inoculation, when the agar plates tested were inoculated with aliquots obtained from the same selective enrichment broth, those plates did not show significant difference in recovery of Salmonella sp. Nevertheless, the number of false-positive colonies taken from the agars decreased, mainly for VB. 
Table 1. Recovery of different Salmonella serotypes from artificially contaminated feces of swine using four different selective enrichment broths.

\begin{tabular}{lcccccc}
\hline \multirow{2}{*}{ Assay } & \multirow{2}{*}{ Serotype } & \multirow{2}{*}{$\begin{array}{c}\text { No. of } \\
\text { plates }\end{array}$} & \multicolumn{4}{c}{$\begin{array}{c}\text { No. of plates positive for } \\
\text { Salmonella }\end{array}$} \\
\cline { 3 - 7 } & & streaked & RV & TMK42 & SC & TMK37 \\
\hline \multirow{2}{*}{$1^{\text {st }}$} & S. Enteriditis & 18 & $10^{c}$ & $17^{c, g}$ & $0^{d}$ & $7^{c, f}$ \\
& S. Typhimurium & 18 & $18^{g}$ & $17^{g}$ & $0^{h}$ & $14^{g}$ \\
& Pool $^{b}$ & 18 & $18^{g}$ & $18^{g}$ & $5^{h}$ & $13^{g}$ \\
\hline \multirow{2}{*}{$2^{\text {nd }}$} & S. Enteriditis & 18 & 1 & 0 & 2 & 4 \\
& S. Typhimurium & 18 & 17 & 17 & 18 & 17 \\
& Pool $^{b}$ & 18 & $18^{i}$ & $18^{i}$ & $8^{i}$ & $18^{i}$ \\
\hline
\end{tabular}

${ }^{a}$ RV. Rappaport-Vassiliadis; TMK42, Tetrathionate MüllerKauffmann incubated at $42^{\circ} \mathrm{C}$; TMK37 Tetrathionate MüllerKauffmann incubated at $37^{\circ} \mathrm{C}$; SC, Selenite Cystine; ${ }^{b}$ Salmonella sp., S. Bredeney and S. Derby; ${ }^{c, d o r e, f}$ different letters in the same line indicate differences with $\mathrm{p}<0.05 ;^{g, h}$ different letters in the same line indicate differences with $p<0.002 ;{ }^{i, j}$ different letters in the same line indicate differences with $\mathrm{p}<0.03$.

\section{Naturally contaminated samples}

Due to the low yield in the first experiment and toxicity, SC was not tested in the second experiment. However, this broth figures among the most commonly used enrichment steps to isolate Salmonella sp. from food and animal feed (4). As the use of more than one enrichment broth increases the chances to isolate Salmonella sp., RV, TMK42, and TMK37 were further tested with naturally contaminated samples (4).

When comparing broth efficiency, TMK42 was significantly superior $(p<0.0001)$ than RV and TMK37, in the first sampling trial (Table 2). In the second sampling trial, TMK42 besides RV performed better than TMK37, but only TMK42 showed significant difference when compared to TMK37 (Table 2). In this visit to the farm, fewer animals were excreting Salmonella, so the overall isolation was lower in comparison to the first visit.

In both trials, the recovery of Salmonella sp. in agar XLT4 and VB showed no significant difference when inoculated with $\mathrm{RV}$ and TMK42. Only in the first sampling trial, XLT4 performed significantly better $(p<0.006)$ than VB, after being inoculated with aliquots of TMK37 (data not shown).

In the first sampling trial TMK42 was the most sensitive enrichment in association with either XLT4 or VB. The association of RV and TMK37 with XLT4 showed the same performance, but the isolation in RV/VB was better than TMK37/ VB association. In the second sampling trial, there was no difference between RV and TMK42, but both presented greater sensitivity than TMK37 when inoculated on any of the agar media (Table 3).
Enrichment with RV showed higher specificity, in the first sampling trial, whereas TMK42 and TMK37 were less specific when associated with VB agar. In the second sampling trial, results were similar for all tested associations (Table 3).

On the whole, comparison of enrichment protocols - either with artificial contamination or after isolation of Salmonella from feces of infected animals - points to a better performance of the TMK incubated at $42^{\circ} \mathrm{C}$. In the second experiment, RV broth inoculated either on XLT4 or on VB, showed greater specificity in both sampling trials. However, in regards to sensitivity, especially in the first trial, RV was far less sensitive than TMK42.

The plating media inoculated with aliquots from the same selective enrichment broth showed no marked difference in the isolation of Salmonella from artificially contaminated samples. Yet, for the first sampling in the second phase, XLT4 proved to be statistically superior to VB, when inoculated with TMK37 (data not shown). This is primarily due to the lower sensitivity of the association TMK37/VB than the association TMK37/XLT4 (Table 3). Nonetheless, the use of VB is indicated

Table 2. Recovery of Salmonella sp. from naturally contaminated feces of swine using three selective enrichment broths.

\begin{tabular}{ccccc}
\hline \multirow{2}{*}{ Assay } & \multirow{2}{*}{ No. of plates } & \multicolumn{3}{c}{$\begin{array}{c}\text { No. of plates positive } \\
\text { for Salmonella }\end{array}$} \\
\cline { 3 - 5 } & streaked & $\mathrm{RV}$ & TMK42 & TMK37 \\
\hline $1^{\text {st }}$ & 252 & $36^{b}$ & $90^{c}$ & $30^{b}$ \\
$2^{\text {nd }}$ & 252 & 10 & $12^{d}$ & $5^{e}$ \\
\hline
\end{tabular}

${ }^{a}$ RV. Rappaport-Vassiliadis; TMK42, Tetrathionate MüllerKauffmann incubated at $42^{\circ} \mathrm{C}$; TMK37 Tetrathionate MüllerKauffmann incubated at $37^{\circ} \mathrm{C} ;{ }^{b, c}$ different letters in the same line indicate differences with $\mathrm{p}<0.0001 ;^{d, e}$ different letters in the same line indicate differences with $\mathrm{p}<0.05$.

Table 3. Sensitivity and specificity of the three selective enrichment steps, associated to two selective agars to isolate Salmonella sp from naturally contaminated swine fecal samples.

\begin{tabular}{cccccccc}
\hline Performance Sampling & \multicolumn{3}{c}{ RV } & \multicolumn{2}{c}{ TMK42 } & \multicolumn{2}{c}{ TMK37 } \\
\cline { 3 - 7 } & & XLT4 & VB & XLT4 & VB & XLT4 & VB \\
\hline Sensitivity & $1^{\text {st }}$ & 36 & 32 & 92 & 81 & 40 & 17 \\
$(\%)$ & $2^{\text {nd }}$ & 71 & 71 & 86 & 86 & 43 & 29 \\
\hline Specificity & $1^{\text {st }}$ & 100 & 100 & 98 & 87 & 96 & 91 \\
$(\%)$ & $2^{\text {nd }}$ & 100 & 99 & 100 & 100 & 100 & 97 \\
\hline
\end{tabular}

${ }^{a}$ RV. Rappaport-Vassiliadis; TMK42, Tetrathionate MüllerKauffmann incubated at $42^{\circ} \mathrm{C}$; TMK37 Tetrathionate MüllerKauffmann incubated at $37^{\circ} \mathrm{C} ;{ }^{b} \mathrm{XLT} 4$, Xylose Lysine-Tergitol 4; VB, Brilliant-Green Phenol-Red Lactose Sucrose agar. 
because it increases the likelihood of isolating Salmonella sp., especially the $\mathrm{H}_{2} \mathrm{~S}$-late producing/ non-producing atypical Salmonella sp. (18).

Whenever differences were seen between combinations of selective broths and agars, these differences were more outstanding when XLT4 was used. This medium presented better conditions for isolation of Salmonella sp. colonies, reducing the number of false-positives. Consequently, better selectivity and better indicator system of XLT4 resulted in greater detection of Salmonella sp., mainly when streaked from a selective enrichment that avoids the overgrow of competitors, this was more difficult to happen when TMK37 was streaked.

Selectivity of enrichment broths is more important than agars. However, the importance of the selectivity of agars increases when Salmonella sp. counts are low, and the detection of the pathogen becomes more difficult. Selectivity of agars is more relevant when detection of Salmonella sp. in samples is done without a selective enrichment step. Selectivity of agars to detect Salmonella sp. has been decreased as the indicator system for identification of Salmonella colonies was improved (7).

The present study constitutes an initial framework to fulfill the local needs for Salmonella sp. isolation protocols. Despite the restrictions of these culture methods their proper use may improve the sensitivity and/or specificity of other methods under standardization for detection of Salmonella sp. Better methods for Salmonella sp. detection will result in better epidemiological investigations of this pathogen.

\section{ACKNOWLEDGMENTS}

This study was supported by CAPES and FAPERGS, Rio Grande do Sul, Brazil. We would like to thank Marjo Cadó Bessa, Lúcia Helena Niederauer Weiss, Ricardo Nonnig, Dra. Carla Lange, Dra. Verônica Schmidt for the useful enlightenment and advice.

\section{RESUMO}

\section{Comparação de diferentes etapas de enriquecimento seletivo no isolamento de Salmonella sp. de fezes de suínos de terminação}

Através de um estudo em duas fases comparou-se a eficiência de etapas de enriquecimento seletivo, associadas a diferentes meios seletivos, na recuperação de Salmonella sp. de fezes de suínos de terminação. Em uma primeira fase, as amostras foram contaminadas artificialmente e os caldos Rappaport-Vassiliadis (RV) incubado a $42^{\circ} \mathrm{C}$, Tetrationato Müller-Kauffmann a $37^{\circ} \mathrm{C}$ (TMK37) e $42^{\circ} \mathrm{C}$ (TMK42), e Selenito Cistina (SC) a $37^{\circ} \mathrm{C}$ foram testados, em associação com meios sólidos seletivos: ágar Rambach (RA), ágar Xilose-Lisina-
Tergitol 4 (XLT4), e ágar Verde-brilhante Vermelho-neutro Lactose Sacarose (VB). Na segunda fase os caldos RV, TMK37, and TMK42, semeados nos meios XLT4 and VB, foram testados com amostras naturalmente contaminadas. No isolamento de Salmonella sp. em amostras artificialmente contaminadas o RV, TMK42 e TMK37 foram superiores ao SC. Na segunda fase o TMK42 e RV foram mais eficientes que o TMK37. O desempenho destas etapas de enriquecimento seletivo influenciou diretamente a capacidade seletiva e indicadora dos meios sólidos seletivos utilizados. No presente estudo, a associação TMK42/ XLT4 demonstrou ser a mais sensível, e a RV/XLT4 a mais específica. O uso do meio VB também é recomendado para aumentar a probabilidade do isolamento de colônias atípicas de Salmonella - produtoras tardias ou não produtoras de $\mathrm{H}_{2} \mathrm{~S}$. No presente estudo, RV e TMK42 foram as etapas de enriquecimento seletivo mais eficientes para o isolamento de Salmonella de fezes de suínos.

Palavras-chave: Salmonella sp., enriquecimento seletivo, suínos

\section{REFERENCES}

1. Alves, J.C.; Lázaro, S.; Hofer, E.; Reis, E.M.S.; Rodrigues, D.P. Salmonella sp. em linfonodos de suínos normais abatidos no Estado do Rio de Janeiro. R. Bras. Med. Vet., 16: 172-176, 1994.

2. Bager, F.; Petersen, J. Sensitivity and specificity of different methods for the isolation of Salmonella from pigs. Acta Vet. Scand., 32: 473-481, 1991.

3. Baggensen, D.L.; Sorensen, L.L.; Krause, P.; Gerner-Smidt, P. The occurrence of Salmonella enteric serotypes in animal feed, pig, pork and man. II International Symposium on Epidemiology and Control of Salmonella in Pork, Copenhagen, 1997, p. 5659.

4. Bailey, J.S.; Cox, N.A.; Thompson, J.E. Efficiency of selenite cystine and TT enrichment broths for the detection of Salmonella. J. Appl. Bacteriol., 51: 409-414, 1981.

5. Bessa, M.C.; Costa, M.; Cardoso, M. Prevalence of Salmonella sp. in slaughtered pigs in Rio Grande do Sul, Brazil. IV International Symposium on Epidemiology and Control of Salmonella and other Food Borne Pathogens in Pork, Leipzig, 2001, p. $189^{1}-191$.

6. Borch, E.; Nesbakken, T.; Christensen, H. Hazard identification in swine slaughter with respect to foodborne bacteria. Int.J.Food Microbiol., 30: 9-25, 1996.

7. Busse, M. Media for Salmonella. Int. J. Food Microbiol., 26: 117 131, 1995.

8. Christensen, J.; Hillersborg, M.; Baggensen, D.L. Detection of Salmonella enteric in subclinically infected herds. II International Symposium on Epidemiology and Control of Salmonella in Pork, Copenhagen, 1997, p. 188-191.

9. Davies, R.H.; Dalziel, R.; Wilesmith, J.W.; Ryan, J.; Evans, S.J.; Paiba, G.A.; Byrne, C.; Pascoe, S. National survey for Salmonella in pigs at slaughter in Great Britain. IV International Symposium on Epidemiology and Control of Salmonella and other Food Borne Pathogens in Pork, Leipzig, 2001, p. 162-173.

10. Funk, J.A.; Davies, P.R.; Nichols, M.G. Evaluation of sample weight for the isolation of Salmonella spp. from swine feces. II International Symposium on Epidemiology and Control of Salmonella in Pork, Washington, 1997, p. 97-99. 
11. Graphpad Instat. Versão 2,01, São Paulo: Graphpad Software, 19901993.

12. Harris, I.T. Salmonella in swine feed: Salmonella Seminar. The Allen D. Leman Swine Conference, Minnesota, 1996, p. 29-38.

13. Holt, J.G.; Krieg, N.R.; Sneath, P.H.A.; Stanley, J.T.; Williams, S.T. (Eds). Bergey's manual of determinative bacteriology. Williams \& Wilkins, 1994, p. 186-187.

14. June, G.A.; Sherrod, P.S.; Hammack, T.S.; Amagua, M.R.; Andrews, W.H. Relative effectiveness of selenite cystine broth, tetrathionate broth, and Rappaport-Vassiliadis medium for the recovery of Salmonella from raw flesh and other highly contaminated foods: precollaborative study J. AOAC Int., 78: 375-380, 1995.

15. Ludewig, M.; Ahrens, A.; Fehlhaber, K. Comprehensive serological and bacteriological investigations of Salmonella prevalence of slaughtered swine in Saxony (Germany). IV International Symposium on Epidemiology and Control of Salmonella and other Food Borne Pathogens in Pork, Leipzig, 2001, p. 195-197.

16. Martins, C. Fatos e perspectivas mundiais na oferta e demanda da carne suína. XIX Congresso Brasileiro de Veterinários Especialistas em Suínos, Belo Horizonte, 1999. p. 53-61.

17. Moriñigo, M.A.; Martinez-Manzanares, E.; Muñoz, A.; Cornax, R.; Romero, P.; Borrego, J.J. Evaluation of different plating media used in the isolation of Salmonellas from environmental samples. $J$. Appl. Bacteriol., 66: 353-360, 1989.
18. Nielsen, B.; Baggesen, D.L. Update on laboratory diagnosis of subclinical Salmonella infections in pigs. II International Symposium on Epidemiology and Control of Salmonella in Pork, Copenhagen, 1997. p. 19-31.

19. Pignato, S.; Marino, A.M.; Emanuele, M.C.; Iannotta, V.; Caracappa, S.; Giammanco, G. Evaluation of new culture media for rapid detection and isolation of Salmonellae in foods. Appl. Enviromen. Microbiol., 61: 1996-1999, 1995.

20. Rhodes, P.; Quesnel, L.B.; Collard, P. Growth kinetics of mixed culture in Salmonella enrichment media. J. Appl. Bacteriol., 59: 231-237, 1985.

21. Sherrod, P.S.; Amaguana, R.M.; Andrews, W.H.; June, G.A.; Hammack, T.S. Relative effectiveness of selective plating agars for recovery of Salmonella species from selected high-moisture foods. J. AOAC Int., 78: 679-690, 1995.

22. Torrence, M.E. Surveillance. Understanding epidemiology. St. Louis: Mosby, 1997. p. 165-169.

23. Wegener, H.C.; Bager, F. Pork as a source of human salmonellosis. II International Symposium on Epidemiology and Control of Salmonella in Pork, Copenhagen, 1997. p. 3-8.

24. Weiss, L.H.N.; Nonnig, R.; Cardoso, M.R.I.; Costa, M. Occurence of Salmonella in finishing pigs in south Brazil. II International Symposium on Epidemiology and Control of Salmonella in Pork, Washington, 1999. p. 184-185. 